\title{
SOWING TIME AND MANAGEMENT EFFECTS ON PHENOLOGY, GROWTH AND YIELD OF GARDEN PEA
}

\author{
S.S. Kakon ", M.M. Sheikh ${ }^{1}$, M.S.A. Khan ${ }^{2}$, A.A.Begum", J.A. Chowdhury " and M.A.Hossain ${ }^{3}$ \\ *Agronomy Division, Bangladesh Agricultural Research Institute, Joydebpur,Gazipur \\ ${ }^{1}$ Regional Agricultural Research Station, BARI, Burirhat,Rangpur \\ ${ }^{2}$ Training and Communication wing, BARI, Gazipur \\ ${ }^{3}$ On-farm Research Division, BARI, Gazipur, 1701, Bangladesh \\ Corresponding E-mail: kakonbari@gmail.com
}

(Received: 09 September, 2020, Accepted: 13 October, 2020)

Key words: Temperature, phenology, sowing date, management practices, yield, garden pea

\begin{abstract}
The experiment was conducted at the research field of the Agronomy Division, Bangladesh Agricultural Research Institute (BARI), Gazipur and Regional Agricultural Research Stations (RARS), Burirhat during two successive rabi seasons of 2015 and 17 to find out the relation between different development events of garden pea (Pisum sativum L.) and the sowing time based temperature, and also to minimize the yield reduction by adopting appropriate management practices. The treatments comprised with three sowing dates (30 November, 15 December and 30 December) and three management practices (low, medium and high). Under high management, Nov. 30 sowing took maximum days (64 days in 2015-16 and 58 days in 2016-17 at Joydebpur and 58 days in 2015-16 and 57 days in 2016-17 at RARS, Burirhat) to reach harvesting maturity. The results indicated that the number of days required for attaining different phenological stages decreased with delay of sowing. Late sowing took minimum time from flowering to fresh pod maturity (51 days and 49 days in two years at Joydebpur, and 49 days and 46 days in two years at Burirhat) due to increase in minimum temperature. The results revealed that the highest pod yield (14.77 $\mathrm{t} \mathrm{ha}^{-1}$ in 2015-16 and 13.09 $\mathrm{t} \mathrm{ha}^{-1}$ in 2016-17 at Joydebpur and 9.63 tha $^{-1}$ in 2015-16 and $10.33 \mathrm{t} \mathrm{ha}^{-1}$ in 2016-17 at Burirhat) was recorded from 30 November sowing with high management practices which was followed by 15 December with the same management. Yield reduction in late sowing was reduced to some extent by high management practices. The two year results revealed that 30 November sowing with high management practices (extra 20\% recommended fertilizer dose, HRC + two irrigation at pre flowering and pod development stage + seed treatment + one weeding at $21 \mathrm{DAE}$ ) showed better pod yield than other combinations.
\end{abstract}

\section{Introduction}

Pea (Pisum sativum L.) is commonly used in human diet throughout the world and it is rich in protein (21-25\%), carbohydrates, vitamin A and $\mathrm{C}, \mathrm{Ca}$, phosphorous and has high levels of amino acids lysin and trytophan (Bhat et al., 2013). Average green pod yield per unit area of the crop in the country is quite low as compared to some other countries. The garden pea is grown mainly for young pod to get tender green seeds as vegetable. The crop has gained popularity for its short durability and high nutritive value. Besides this, a huge amount of garden pea is consumed as soup. Garden pea can play an important role to overcome our national protein deficit. Its demand especially to the urban people is increasing day by day. Edible-pod peas prefer consistently cool growing conditions rather than hotter areas (Slinkard et al., 1994).

Among the climatic factors, temperature plays a key role in determining sowing time and consequently the duration of different phenophases and thus the crop productivity (Tewari and Singh, 1993). Further, 
delay in sowing may not permit proper vegetative growth of the crop and it may face high temperature at its later growth stages leading to forced maturity and low productivity. Garden pea is a cool loving crop and winter is becoming shorter due to climate change, consequently the crop may be affected. It is mostly grown after aman rice in rice based cropping pattern. Temperature above $30^{\circ} \mathrm{C}$ is harmful for garden pea (Sousa-Majer et al., 2004). Global temperature is rising. Developing seeds exposed to high temperature was found aborted and reduction in pea seed yield (Jeuffroy, 1990). High-temperature stress affects reproductive development, as reported in legumes such as chickpea (Kaushal et al., 2013; Kumar et al., 2013) and pea (Guilioni et al., 1997). It was reported that different environmental conditions, especially temperature due to different sowing time provide variable in crop growth, development and yield stability (Ali et al., 2016). It is also needed to minimize the yield reduction by taking different management. So, the experiment was conducted to evaluate the crop growth and yield performance under different management practices.

\section{Materials and Methods}

The experiment was conducted at the research field of the Agronomy Division, Bangladesh Agricultural Research Institute (BARI), Joydebpur, Gazipur and RARS, Burirhat during rabi season of 2015-16 and 2016-17.The soil was silty clay in texture with $\mathrm{pH}$ of 6.5. The crops received no rainfall at Joydebpur, Gazipur and RARS, Burirhat during the crop season of 2015-16 and 2016-17. The treatments were comprised with three sowing dates; i. 30 November $\left(D_{1}\right)$, ii. 15 December $\left(D_{2}\right)$ and iii. 30 December $\left(\mathrm{D}_{3}\right)$ and management practices; i. Low: 25-30-56-5 $\mathrm{kg}$ NPKS/ha, no irrigation, no weeding, no pesticide $\left(\mathrm{M}_{1}\right)$. ii. Medium: $25-30-56-5 \mathrm{~kg} \quad \mathrm{NPKSha}^{-1}$, one weeding at $21 \mathrm{DAE}$, two irrigations at pre flowering and pod development stages and spraying pesticides (Dithane $\mathrm{M}-45)\left(\mathrm{M}_{2}\right)$. iii. High: 30-36-67-6 NPKS kgha ${ }^{-1}$ (Recommended dose + extra 20\% recommended dose, HRC+ two irrigation at pre flowering and pod development stage, seed treatment(Seeds were treated with Vitavex$200 @ 2.5 \mathrm{~g} \mathrm{~kg}^{-1}$ seeds before 24 hours of sowing), one weeding at $21 \mathrm{DAE}\left(\mathrm{M}_{3}\right)$. The experiment was laid out in a split-plot design with three replications. The sowing dates were assigned in the main plots and management practices were arranged in sub-plots. Garden pea var. BARI motorshuti-3 was used as test crop. Seeds were sown in lines with maintaining $30 \mathrm{~cm}$ row to row spacing. Half of urea and full doses of other fertilizers were applied at the time of final land preparation. The remaining half of urea was top dressed at flowering stage followed by irrigation. In case of low management, all fertilizers were applied at the time of final land preparation. Insecticide was sprayed in the respective treatment plots. At flowering stage, plant samples were collected from an area of one square meter of all treatments and the plant samples were dried in an oven for 72 hours at $80^{\circ} \mathrm{C}$ and then dry weights were recorded. The phenological data were recorded by field monitoring every day. The yield component data was collected from 10 randomly selected plants prior to harvest from each plot. Meteorological data for air temperature and rainfall were obtained from meteorological station located adjacent to the experiment field. At later stage of cropping season rust disease was visible. Rust disease was controlled by Tilt only Joydebpur. At harvest, the yield data was recorded plot wise and analyzed statistically by MSTAT-C and means were compared using Least Significant Difference (LSD).

\section{Results and Discussion}

\section{Days for development events}

The phenological stages of garden pea may be broadly classified as emergence, flowering, 50\% flowering, pod set and fresh pod. The number of days required for different development events of garden pea grown under different sowing dates and management practices over the years and over the locations have been presented in Table 1. All the phonological events varied on sowing dates and management practices. Emergence of early sown crop occurred 1 days earlier than those of late sown. Late sowing reduced the length of vegetative growth stage causing early flowering. The 30 November 
sowing took maximum days for first flowering (32 days and 29 days in both the years at Joydebpur and 31 days for two years at Burirhat) and 50\% flowering (35 days for two locations in 2015-16 and 31 days in 2016-17 at Joydebpur and 34 days in 2016-17 at Burirhat) whereas 30 December sowing took minimum days for first flowering (26 days in 2015-16 and 28 days in 2016-17 at Joydebpur and 28 days in 2015-16 and 26 days in 2016-17 at Burirhat) and 50\% flowering (29 days in two years over the locations).The days for harvesting maturity (fresh pod ) varied by sowing date and management practices.

Table 1. Number of days required for attaining different developmental events of garden pea grown at different sowing dates under different management practices during rabi season of 2015-16 and 2016-17 at Joydebpur and RARS, Burirhat

\begin{tabular}{|c|c|c|c|c|c|c|c|c|c|}
\hline \multicolumn{2}{|c|}{ Treatments } & \multicolumn{8}{|c|}{ Developmental events } \\
\hline \multirow[t]{3}{*}{ Sowing dates } & \multirow[t]{3}{*}{ Management } & \multicolumn{4}{|c|}{ Emergence } & \multicolumn{4}{|c|}{ Days to ${ }^{\text {st }}$ flower initiation } \\
\hline & & \multicolumn{2}{|c|}{ 2015-16 } & \multicolumn{2}{|c|}{ 2016-17 } & \multicolumn{2}{|c|}{$2015-16$} & \multicolumn{2}{|c|}{ 2016-17 } \\
\hline & & Joy. & Bur. & Joy. & Bur. & Joy. & Bur. & Joy. & Bur. \\
\hline \multirow[t]{3}{*}{30 Nov. } & Low & 6 & 7 & 6 & 7 & 32 & 31 & 29 & 31 \\
\hline & Medium & 6 & 6 & 6 & 7 & 32 & 31 & 29 & 30 \\
\hline & High & 6 & 7 & 6 & 7 & 32 & 30 & 29 & 28 \\
\hline \multirow[t]{3}{*}{15 Dec. } & Low & 6 & 7 & 6 & 8 & 27 & 28 & 29 & 27 \\
\hline & Medium & 6 & 7 & 6 & 7 & 27 & 28 & 29 & 27 \\
\hline & High & 6 & 6 & 6 & 7 & 27 & 27 & 29 & 26 \\
\hline \multirow[t]{3}{*}{30 Dec. } & Low & 7 & 8 & 8 & 8 & 26 & 27 & 28 & 26 \\
\hline & Medium & 7 & 8 & 8 & 8 & 26 & 27 & 28 & 26 \\
\hline & High & 7 & 7 & 8 & 7 & 26 & 27 & 28 & 25 \\
\hline
\end{tabular}

Table 1. Cont'd

\begin{tabular}{|c|c|c|c|c|c|c|c|c|c|}
\hline \multicolumn{2}{|c|}{ Treatments } & \multicolumn{8}{|c|}{ Developmental events } \\
\hline \multirow{3}{*}{ Sowing dates } & \multirow[t]{3}{*}{ Management } & \multirow{2}{*}{\multicolumn{4}{|c|}{\begin{tabular}{|cc} 
Days to $50 \%$ flower & initiation \\
$2015-16$ & $2016-17$ \\
\end{tabular}}} & \multicolumn{4}{|c|}{ Fresh pod } \\
\hline & & & & & & \multicolumn{2}{|c|}{$2015-16$} & \multicolumn{2}{|c|}{ 2016-17 } \\
\hline & & Joy. & Bur. & Joy. & Bur. & Joy. & Bur. & Joy. & Bur. \\
\hline \multirow[t]{3}{*}{30 Nov. } & Low & 35 & 35 & 31 & 34 & 62 & 58 & 56 & 55 \\
\hline & Medium & 35 & 34 & 31 & 33 & 64 & 60 & 58 & 57 \\
\hline & High & 35 & 34 & 31 & 32 & 64 & 61 & 58 & 57 \\
\hline \multirow[t]{3}{*}{15 Dec. } & Low & 29 & 31 & 31 & 30 & 56 & 53 & 52 & 50 \\
\hline & Medium & 29 & 31 & 31 & 30 & 57 & 54 & 54 & 52 \\
\hline & High & 29 & 30 & 31 & 30 & 57 & 55 & 55 & 52 \\
\hline \multirow[t]{3}{*}{30 Dec. } & Low & 29 & 29 & 29 & 29 & 51 & 49 & 49 & 46 \\
\hline & Medium & 29 & 29 & 29 & 28 & 55 & 52 & 51 & 48 \\
\hline & High & 29 & 29 & 29 & 27 & 55 & 53 & 51 & 48 \\
\hline
\end{tabular}

The 30 November sowing took maximum days (64 days in 2015-16 and 58 days in 2016-17 at Joydebpur and 58 days in 2015-16 and 57 days in 2016-17at Burirhat). Low management practices took minimum days for harvesting fresh pod and both the medium and high management practices took maximum days. The minimum days for harvesting maturity were found in 30 December sowing (51 days and 49 days in two years at Joydebpur 49 days and 46 days in two years at Burirhat) at low management practices. The maximum days needed for pod harvest (64 days in 2015-16 and 58 days in 2016-17) was recorded both medium and high management practices at 30 Nov. sowing. The reasons for variation in growth duration might be due to variation in day and night temperature and in increased temperature at the later sowing.

The mean temperatures during crop duration varied across the sowing dates over the years and over the locations (Table $2 \mathrm{a}$ and $2 \mathrm{~b}$ ). The late sown crop received comparatively higher temperatures from emergence to $1^{\text {st }}$ flowering and $50 \%$ flowering to maturity stages than those of early sown ones. At 30 
Dec. sowing, from emergence to $1^{\text {st }}$ flowering the maximum and minimum temperature were $\left(27^{0} \mathrm{C}\right.$ and $19.60^{\circ} \mathrm{C}$ in $2015-16$ and $31.35^{\circ} \mathrm{C}$ and $12.60^{\circ} \mathrm{C}$ in $2016-17$ ), respectively at Joydebpur. From $50 \%$ flowering to harvesting maturity the maximum and minimum temperature were $\left(29.65^{\circ} \mathrm{C}\right.$ and $11.99^{\circ} \mathrm{C}$ in $2015-16$ and $30.24^{\circ} \mathrm{C}$ and $14.72^{\circ} \mathrm{C}$ in 2016-17), respectively at Joydebpur. At 30 Dec. sowing, from emergence to $1^{\text {st }}$ flowering the maximum and minimum temperature were $\left(28.67^{\circ} \mathrm{C}\right.$ and $16.00^{\circ} \mathrm{C}$ in 2015-16 and $28.70^{\circ} \mathrm{C}$ and $16.80^{\circ} \mathrm{C}$ in $2016-17$ ), respectively. From $50 \%$ flowering to harvesting maturity the maximum and minimum temperature were $\left(22.43^{\circ} \mathrm{C}\right.$ and $11.43^{\circ} \mathrm{C}$ in $2015-16$ and $25.83^{\circ} \mathrm{C}$ and $12.06^{\circ} \mathrm{C}$ in $2016-17$ ), respectively at Burirhat. Late sown crop produced flower early and also matured early than early sown due to prevailing higher minimum and maximum temperatures. Similar results were also observed by Helena and Brodaczewska (2007).

Table 2a. Average mean temperature for different phonological events of Gardenpea (var. BARI Motorshuti-3) as affected by sowing dates at Joydebpur during rabi season of 2015-16

\begin{tabular}{|c|c|c|c|c|c|c|}
\hline \multirow[t]{3}{*}{ Phenological events } & \multicolumn{6}{|c|}{ Sowing dates } \\
\hline & \multicolumn{2}{|c|}{30 November } & \multicolumn{2}{|c|}{15 December } & \multicolumn{2}{|c|}{30 December } \\
\hline & $\begin{array}{l}\text { Min. Tem. } \\
{ }_{0}^{0} \mathrm{C}\end{array}$ & $\begin{array}{c}\text { Max. } \\
\text { Tem. }{ }^{0} \mathrm{C}\end{array}$ & $\begin{array}{l}\text { Min. Tem. } \\
{ }_{0} \mathrm{C}\end{array}$ & $\begin{array}{l}\text { Max. } \\
\text { Tem. }{ }^{0} \mathrm{C}\end{array}$ & $\begin{array}{l}\text { Min. Tem. } \\
{ }_{0}^{0} \mathrm{C}\end{array}$ & $\begin{array}{l}\text { Max. } \\
\text { Tem. }{ }^{0} \mathrm{C}\end{array}$ \\
\hline Emergence (days & 18.35 & 29.02 & 17.50 & 24.00 & 15.40 & 26.80 \\
\hline Emergence to $1^{\text {st }}$ flowering & 16.30 & 27.40 & 18.00 & 24.00 & 19.60 & 27.00 \\
\hline $\begin{array}{l}\text { First flowering to } 50 \% \\
\text { flowering }\end{array}$ & 12.40 & 26.70 & 16.23 & 26.03 & 10.93 & 26.15 \\
\hline $\begin{array}{l}50 \% \text { flowering to harvesting } \\
\text { maturity(fresh pod) }\end{array}$ & 11.93 & 24.73 & 12.38 & 25.68 & 11.99 & 29.65 \\
\hline
\end{tabular}

Table 2a. Average mean temperature for different phenological events of Gardenpea (var. BARI Motorshuti-3) as affected by sowing dates at Joydebpur during rabi season of 2016-17

\begin{tabular}{|c|c|c|c|c|c|c|}
\hline \multirow{3}{*}{$\begin{array}{r}\text { Phenological events } \\
\text { (Days) }\end{array}$} & \multicolumn{6}{|c|}{ Sowing dates } \\
\hline & \multicolumn{2}{|c|}{30 November } & \multicolumn{2}{|c|}{15 December } & \multicolumn{2}{|c|}{30 December } \\
\hline & $\begin{array}{l}\text { Min. } \\
\text { Tem. }{ }^{0} \mathrm{C}\end{array}$ & $\begin{array}{c}\text { Max. } \\
\text { Tem. }{ }^{0} \mathrm{C}\end{array}$ & $\begin{array}{l}\text { Min. } \\
\text { Tem. }{ }^{0} \mathrm{C}\end{array}$ & $\begin{array}{c}\text { Max. } \\
\text { Tem. }{ }^{0} \mathrm{C}\end{array}$ & $\begin{array}{l}\text { Min. } \\
\text { Tem. }{ }^{0} \mathrm{C}\end{array}$ & $\begin{array}{c}\text { Max. } \\
\text { Tem. }{ }^{0} \mathrm{C}\end{array}$ \\
\hline Emergence & 16.73 & 30.67 & 14.83 & 27.38 & 12.43 & 27.48 \\
\hline Emergence to $1^{\text {st }}$ flowering & 14.74 & 28.16 & 13.15 & 26.75 & 12.42 & 27.45 \\
\hline $\begin{array}{l}\text { First flowering to } 50 \% \\
\text { flowering }\end{array}$ & 13.00 & 28.06 & 11.33 & 27.46 & 12.60 & 31.35 \\
\hline $\begin{array}{l}50 \% \text { flowering to harvesting } \\
\text { (fresh pod) }\end{array}$ & 11.56 & 26.43 & 13.36 & 28.11 & 14.72 & 30.24 \\
\hline
\end{tabular}

Table 2b. Average mean temperature for different phonological events of Gardenpea (var. BARI Motorshuti-3) as affected by sowing dates at RARS, Burirhat during rabi season of 2015-16

\begin{tabular}{|c|c|c|c|c|c|c|}
\hline \multirow{3}{*}{$\begin{array}{c}\text { Phenological } \\
\text { events }\end{array}$} & \multicolumn{6}{|c|}{ Sowing dates } \\
\hline & \multicolumn{2}{|c|}{30 November } & \multicolumn{2}{|c|}{15 December } & \multicolumn{2}{|c|}{30 December } \\
\hline & $\underset{0}{\operatorname{Min} . ~ T e m . ~}$ & $\underset{{ }_{0} \mathrm{C}}{\operatorname{Max} . \text { Tem. }}$ & $\underset{{ }_{0} \mathbf{C}}{\operatorname{Min} . \text { Tem. }}$ & $\underset{{ }^{0} \mathrm{C}}{\operatorname{Max} . \text { Tem. }}$ & 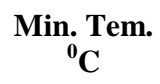 & 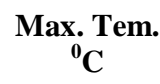 \\
\hline Emergence (days & 17.80 & 28.73 & 17.80 & 28.73 & 16.23 & 27.53 \\
\hline $\begin{array}{l}\text { Emergence to } 1^{\text {st }} \\
\text { flowering }\end{array}$ & 16.00 & 28.67 & 16.40 & 26.07 & 16.20 & 25.60 \\
\hline $\begin{array}{l}\text { First flowering to } \\
50 \% \text { flowering }\end{array}$ & 15.90 & 20.67 & 13.53 & 24.93 & 11.50 & 23.40 \\
\hline $\begin{array}{l}50 \% \text { flowering to } \\
\text { harvesting } \\
\text { maturity(fresh }\end{array}$ & 11.43 & 22.43 & 12.47 & 24.33 & 13.33 & 26.73 \\
\hline
\end{tabular}


pod)

Table 2b. Average mean temperature for different phonological events of Gardenpea (var. BARI Motorshuti-3) as affected by sowing dates at RARS, Burirhat during rabi season of 2016-17

\begin{tabular}{|c|c|c|c|c|c|c|}
\hline \multirow{3}{*}{$\begin{array}{c}\text { Phenological } \\
\text { events } \\
\text { (Days) }\end{array}$} & \multicolumn{6}{|c|}{ Sowing dates } \\
\hline & \multicolumn{2}{|c|}{30 November } & \multicolumn{2}{|c|}{15 December } & \multicolumn{2}{|c|}{30 December } \\
\hline & $\underset{{ }_{0} \mathbf{C}}{\text { Min. Tem. }}$ & $\underset{{ }_{0}}{\operatorname{Max} . \text { Tem. }}$ & $\underset{0}{{ }_{0} \operatorname{Min}_{\mathrm{C}} \mathrm{Tem} .}$ & $\underset{{ }_{0} \mathrm{C}}{\operatorname{Max} . \text { Tem. }}$ & 73 & $\begin{array}{l}\text { Max. Tem. } \\
{ }_{0} \mathrm{C}\end{array}$ \\
\hline Emergence & 17.00 & 28.70 & 16.87 & 28.70 & 16.43 & 28.60 \\
\hline $\begin{array}{l}\text { Emergence to } 1^{\text {st }} \\
\text { flowering }\end{array}$ & 16.80 & 28.70 & 16.40 & 28.33 & 15.47 & 28.00 \\
\hline $\begin{array}{l}\text { First flowering to } \\
50 \% \text { flowering }\end{array}$ & 12.13 & 25.33 & 11.60 & 24.00 & 13.90 & 27.77 \\
\hline $\begin{array}{l}50 \% \text { flowering to } \\
\text { harvesting (fresh } \\
\text { pod) }\end{array}$ & 12.06 & 25.83 & 12.76 & 26.47 & 14.17 & 27.86 \\
\hline
\end{tabular}

\section{Total dry matter}

At, flowering stage, the total dry matter production of garden pea varied due to different sowing dates and management practices (Fig.1a and 1b) over the years over the locations. At Joydebpur, significantly the highest total dry matter $\left(46.5 \mathrm{gm}^{-2}\right.$ in $2015-16$ and $41.93 \mathrm{gm}^{-2}$ in 2016-17) was recorded in 30 November sowing with high management practices. The lowest total dry matter $\left(14.68 \mathrm{~g} \mathrm{~m}^{-2}\right.$ in 2015-16 and20.79 $\mathrm{g} \mathrm{m}^{-2}$ in 2016-17 and) was recorded at 30 December sowing with low management practices which was identical with medium management practices at the same date of sowing. On the other hand, at Burirhat, the highest total dry matter $\left(40.20 \mathrm{gm}^{-2}\right.$ in $2015-16$ and $42.67 \mathrm{gm}^{-2}$ in $\left.2016-17\right)$ was recorded in 30 November sowing with high management practices. The lowest total dry matter (14.86 $\mathrm{g} \mathrm{m}^{-2}$ in 2015-16 and $16.34 \mathrm{~g} \mathrm{~m}^{-2}$ in 2016-17) was recorded in 30 December sowing with low management practices which was identical with medium management practices at the same date of sowing.

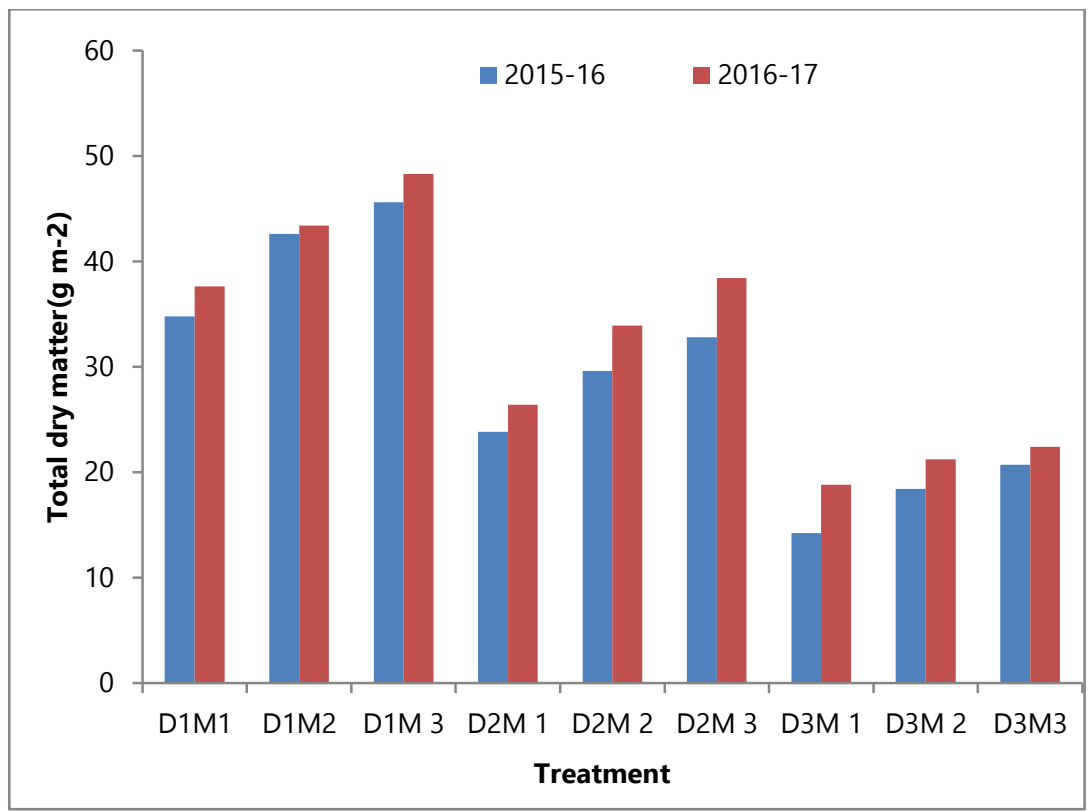


$D_{1}=30$ Nov. $D_{2}=15$ Dec. $D_{3}=30$ Dec., $M_{1}=$ Low management, $M_{2}=$ Medium management, $M_{3}=$ High management

Fig.1a. Total dry matter production of gardenpea at flowering stage under different sowing dates and management practices during 2015-16 and 2016-17 at Joydebpur.

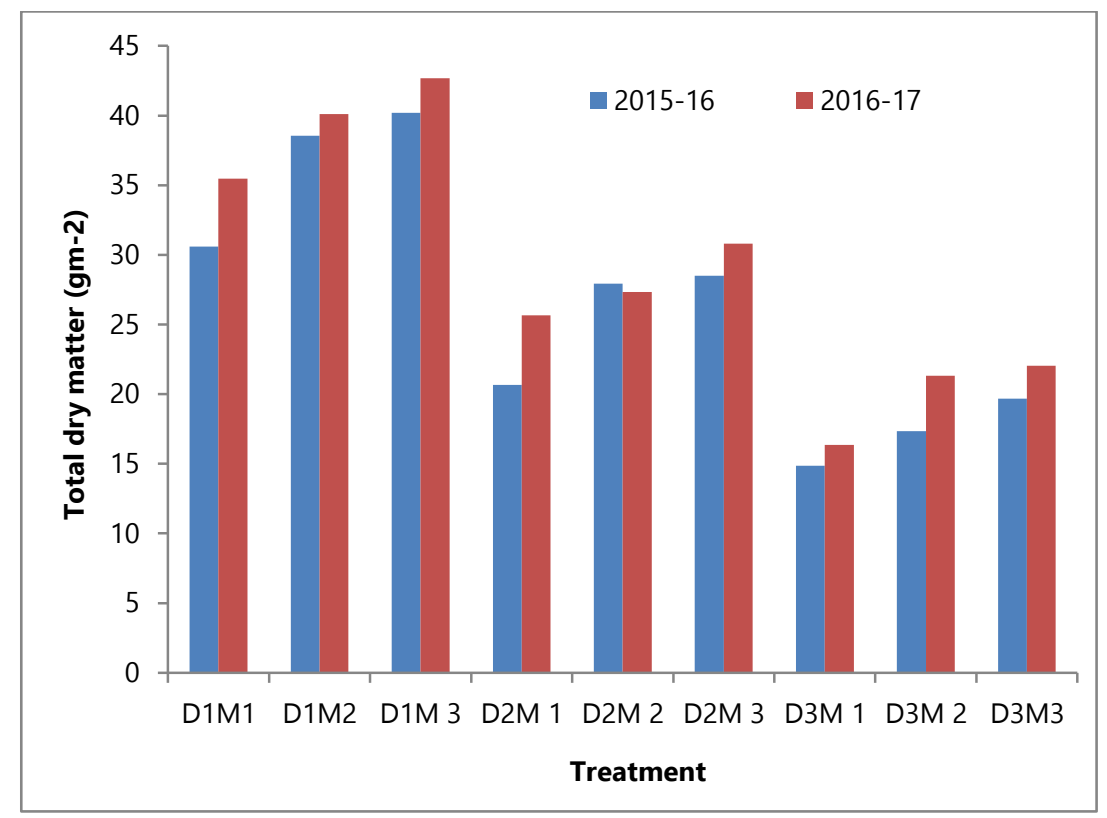

$D_{1}=30$ Nov. $D_{2}=15$ Dec. $D_{3}=30$ Dec., $M_{1}=$ Low management, $M_{2}=$ Medium management, $M_{3}=$ High management

Fig. 1b. Total dry matter production of gardenpea at flowering stage under different sowing dates and Yield and yield attributes

Plant population, plant height, number of pods plant ${ }^{-1}$ and pod yield were significantly different by different sowing dates and management practices over the location over the years (Table 3). Maximum population (14 plant $\mathrm{m}^{-2}$ in 2015-16 and 16 plant $\mathrm{m}^{-2}$ in 2016-17) was recorded in 30 December sowing with high management practices and the lowest $\left(13\right.$ plant $\left.\mathrm{m}^{-2}\right)$ recorded from 30 November sowing with low management practices at Joydebpur. On the other hand, maximum population (15.72plant $\mathrm{m}^{-2}$ in 2015-16 and 14.72 plant $\mathrm{m}^{-2}$ in 2016-17) was recorded in 30 November sowing with high management practices at Burirhat. The tallest plant was recorded from 30 November sowing with high management practices $(48.33 \mathrm{~cm}$ and $43.70 \mathrm{~cm}$ in two years at Joydebpur and $45.20 \mathrm{~cm}$ in $2015-16$ and $52.00 \mathrm{~cm}$ in 2016-17 at Burirhat) which was identical with medium management practices at the same date of sowing (47.67 cm in 2016-17 at Burirhat). The shortest plant was recorded from 30 December sowing with low management practices $36.78 \mathrm{~cm}$ in $2015-16$ and $32.83 \mathrm{~cm}$ in 2016-17 at Joydebpur and $33.13 \mathrm{~cm}$ in 2015-16 and $37.16 \mathrm{~cm}$ in 2016-17 at Burirhat). Significantly the highest number of pods (16.67 plant $^{-1}$ in 2016-16 and 13.45 plant $^{-1}$ in 2016-17 at Joydebpur and 19 plant $^{-1}$ in 2015-16 and 15.00 plant $^{-1}$ in 2016-17 at Burirhat) was recorded in 30 November sowing with high management practices while lowest number of pod in 30 December sowing with low management practices.

Pod yield of garden pea varied significantly under different sowing dates and management practices. Pod yield of garden pea was more at November 30 sowing and decreased towards late sowing. The maximum pod yield also recorded from 30 November sowing with high management practices (14.77 tha ${ }^{-1}$ in 2015-16 and 13.09 $\mathrm{t} \mathrm{ha}^{-1}$ in 2016-17 at Joydebpur and $9.63 \mathrm{t} \mathrm{ha}^{-1}$ in 2015-16 and $10.33 \mathrm{t} \mathrm{ha}^{-1}$ in 2016-17 at Burirhat) which was followed by 15 Dec. sowing of same management practices. The lowest pod yield was obtained from 30 December sowing with low management practices $\left(8.90 \mathrm{t} \mathrm{ha}^{-1}\right.$ in 
2015-16 and $8.70 \mathrm{t} \mathrm{ha}^{-1}$ in 2016-17 at Joydebpur and 5.58 $\mathrm{t} \mathrm{ha}^{-1}$ in 2015-16 and 5.00 $\mathrm{t} \mathrm{ha}^{-1}$ in 2016-17 at Burirhat). The lower pod yield at 30 December sowing might be due to prevailing high temperature during flowering to maturity (Fig. $2 \mathrm{a}$ and $2 \mathrm{~b}$ and Fig.3a and $3 \mathrm{~b}$ ) that hastens forced maturity and reduced TDM production and translocation to the yield components. Similar results were recorded by Ali et al. (2016).

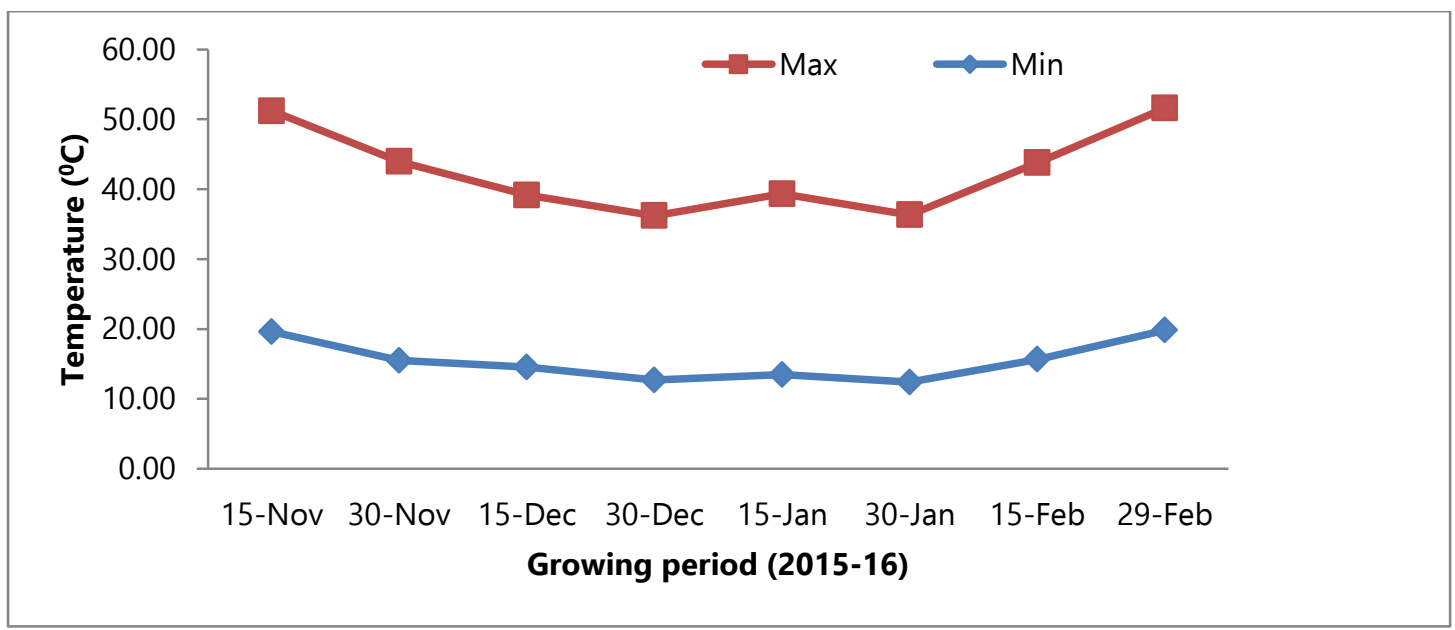

Fig 2a. Maximum and minimum temperature during growing period (2015-2016) at BARI, Joydebpur, Gazipur.

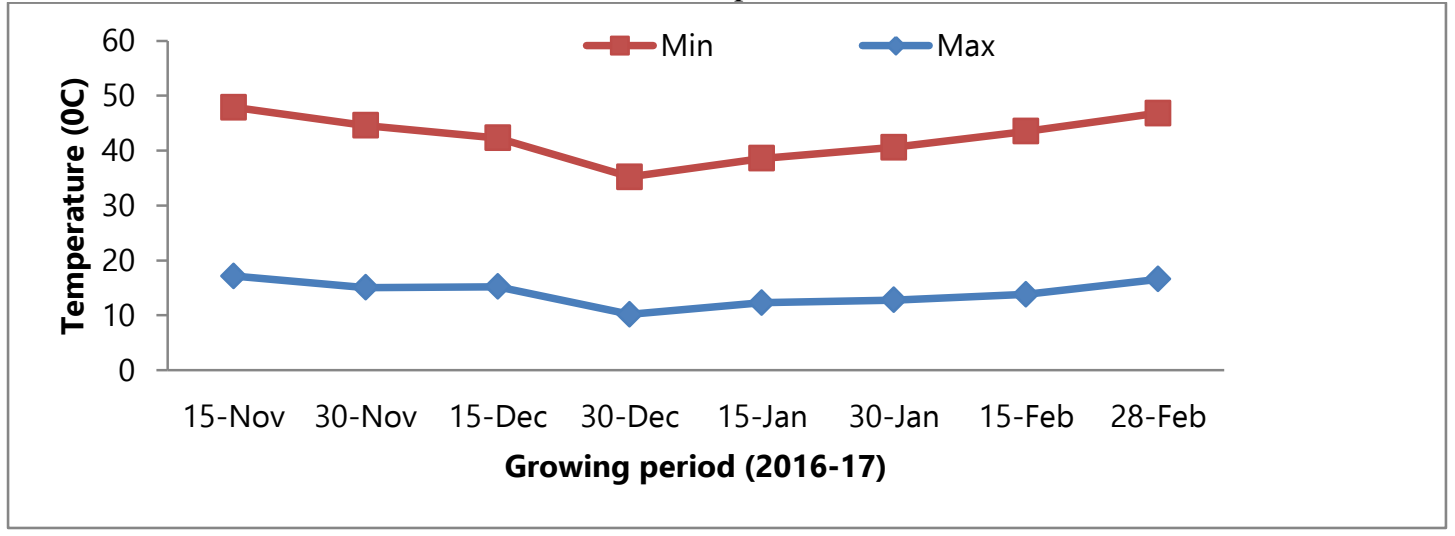

Fig 2b. Maximum and minimum temperature during growing period (2016-2017) at BARI, Joydebpur, Gazipur. 


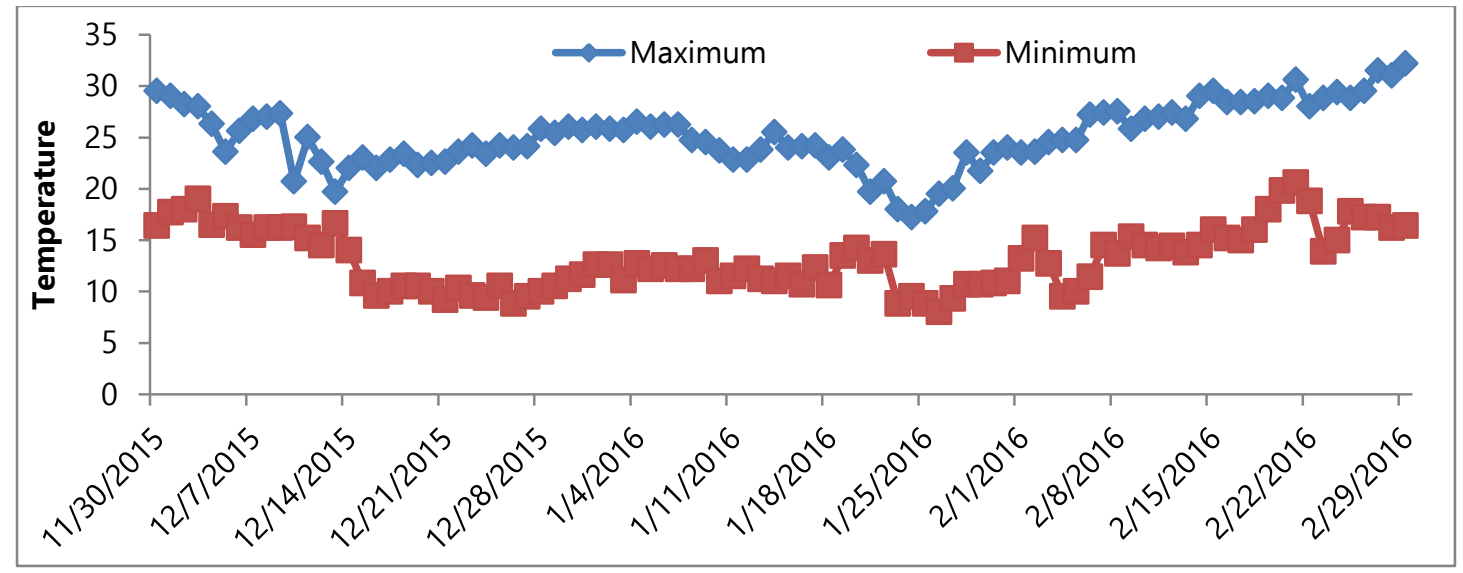

Fig 3a. Weekly mean temperatures (max. and min.) during crop growing period 2015-16 at BARI, RARS, Burirhat.

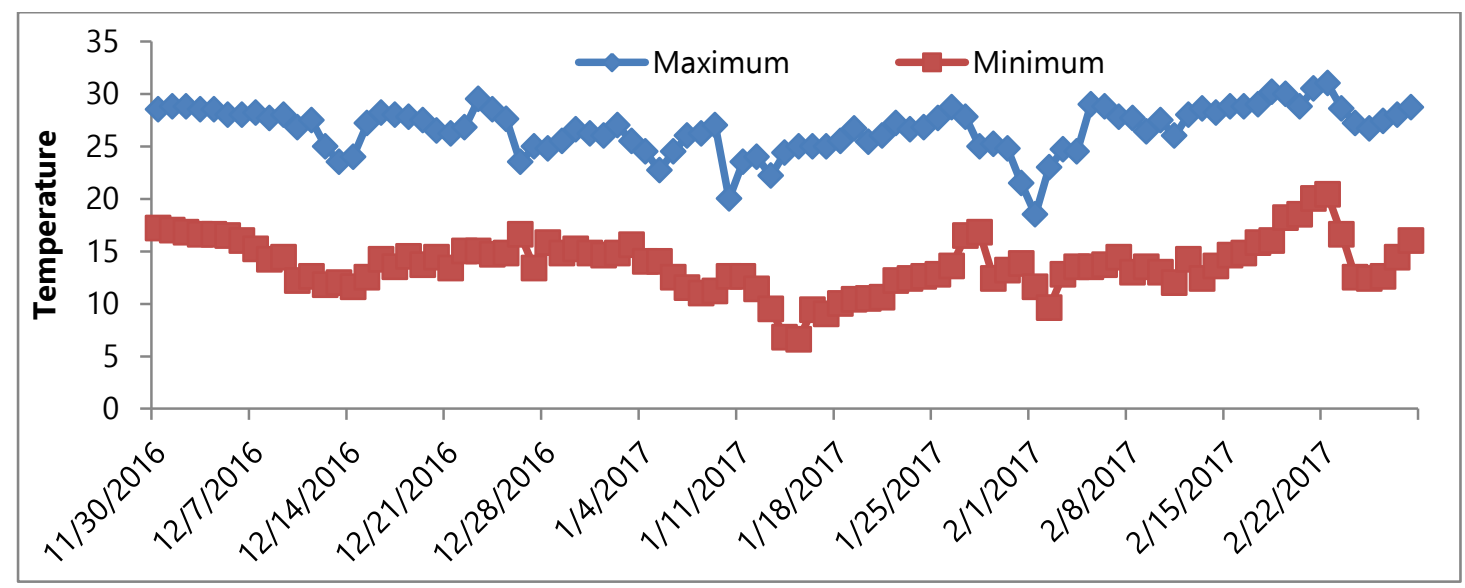

Fig 3b. Weekly mean temperatures (max. and min.) during crop growing period 2016-17 at BARI,

RARS, Burirhat.

This study indicated that raise in temperature reduced the grain growth duration resulted in yield reduction, which in agreement with the findings of Mohanty et al. (2001). It was observed that the pod yield of Dec. 30 sowing was increased from 8.70 to $10.18 \mathrm{t} \mathrm{ha}^{-1}$ through high management practices. It was noted that the crop was partially damaged by rust disease before harvest that resulting poor yield in all treatments at Joydebpur.

Table 3. Plant population, plant height and yield contributing characters and yield of garden pea grown at different sowing dates under different management practices at Joydebpur and RARS, Burirhat during Rabi season 2015-16 and 2016-2017

\begin{tabular}{ccccccccc}
\hline Treatments & \multicolumn{3}{c}{ Plant population $\mathbf{~ m}^{-2}$} & \multicolumn{3}{c}{ Plant height $(\mathbf{c m})$} \\
\cline { 2 - 9 } & \multicolumn{3}{c}{ Joydebpur } & \multicolumn{2}{c}{ Burirhat } & \multicolumn{2}{c}{ Joydebpur } & \multicolumn{2}{c}{ Burirhat } \\
\cline { 2 - 9 } & $\mathbf{2 0 1 5 - 1 6}$ & $\mathbf{2 0 1 6 - 1 7}$ & $\mathbf{2 0 1 5 - 1 6}$ & $\mathbf{2 0 1 6 - 1 7}$ & $\mathbf{2 0 1 5 - 1 6}$ & $\mathbf{2 0 1 6 - 1 7}$ & $\mathbf{2 0 1 5 - 1 6}$ & $\mathbf{2 0 1 6 - 1 7}$ \\
\hline $\mathrm{D}_{1} \mathrm{M}_{1}$ & 10.69 & 12.67 & $13.11 \mathrm{~d}$ & $11.11 \mathrm{~d}$ & 44.62 & 39.16 & $34.60 \mathrm{~cd}$ & $38.40 \mathrm{~d}$ \\
$\mathrm{D}_{1} \mathrm{M}_{2}$ & 10.55 & 14.00 & $14.27 \mathrm{~b}$ & $13.07 \mathrm{~b}$ & 46.78 & 42.00 & $40.63 \mathrm{~b}$ & $43.80 \mathrm{bc}$ \\
$\mathrm{D}_{1} \mathrm{M}_{3}$ & 9.67 & 14.67 & $15.72 \mathrm{a}$ & $14.12 \mathrm{a}$ & 48.33 & 43.70 & $45.20 \mathrm{a}$ & $52.00 \mathrm{a}$ \\
$\mathrm{D}_{2} \mathrm{M}_{1}$ & 10.95 & 14.33 & $14.46 \mathrm{~b}$ & $10.56 \mathrm{~d}$ & 42.03 & 37.09 & $33.07 \mathrm{~d}$ & $37.60 \mathrm{~d}$ \\
$\mathrm{D}_{2} \mathrm{M}_{2}$ & 11.11 & 15.00 & $14.32 \mathrm{~b}$ & $12.62 \mathrm{c}$ & 44.02 & 39.26 & $36.13 \mathrm{bc}$ & $41.80 \mathrm{~cd}$
\end{tabular}




\begin{tabular}{ccccccccc}
$\mathrm{D}_{2} \mathrm{M}_{3}$ & 10.11 & 15.33 & $15.03 \mathrm{a}-\mathrm{c}$ & $12.83 \mathrm{bc}$ & 45.32 & 42.25 & $42.33 \mathrm{ab}$ & $47.67 \mathrm{ab}$ \\
$\mathrm{D}_{3} \mathrm{M}_{1}$ & 12.44 & 15.00 & $13.44 \mathrm{~d}$ & $10.44 \mathrm{~d}$ & 36.78 & 32.83 & $33.13 \mathrm{~d}$ & $37.16 \mathrm{~d}$ \\
$\mathrm{D}_{3} \mathrm{M}_{2}$ & 12.22 & 15.33 & $14.56 \mathrm{~b}$ & $11.56 \mathrm{~d}$ & 38.17 & 34.19 & $35.67 \mathrm{c}$ & $38.40 \mathrm{~d}$ \\
$\mathrm{D}_{3} \mathrm{M}_{3}$ & 14.00 & 16.00 & $15.10 \mathrm{a}-\mathrm{c}$ & $11.10 \mathrm{~d}$ & 39.61 & 36.56 & $37.67 \mathrm{bc}$ & $41.73 \mathrm{~cd}$ \\
\hline $\mathrm{LSD}$ & 1.23 & 1.72 & $*$ & $*$ & 4.66 & 0.12 & $*$ & $*$ \\
$\mathrm{CV}(\%)$ & 6.12 & 6.61 & 5.21 & 3.34 & 6.69 & 6.75 & 5.05 & 6.51 \\
\hline
\end{tabular}

Cont'd

\begin{tabular}{|c|c|c|c|c|c|c|c|c|}
\hline \multirow[t]{3}{*}{ Treatments } & \multicolumn{4}{|c|}{ Pods plant $^{-1}($ no. $)$} & \multicolumn{4}{|c|}{ Pod yield tha ${ }^{-1}$} \\
\hline & \multicolumn{2}{|c|}{ Joydebpur } & \multicolumn{2}{|c|}{ Burirhat } & \multicolumn{2}{|c|}{ Joydebpur } & \multicolumn{2}{|c|}{ Burirhat } \\
\hline & 2015-16 & 2016-17 & 2015-16 & 2016-17 & 2015-16 & 2016-17 & 2015-16 & 2016-17 \\
\hline $\mathrm{D}_{1} \mathrm{M}_{1}$ & 12.53 & 11.91 & $10.73 \mathrm{~d}$ & $10.27 \mathrm{~d}$ & 11.03 & 10.90 & $6.86 \mathrm{~cd}$ & $5.80 \mathrm{e}$ \\
\hline$D_{1} M_{2}$ & 15.00 & 12.87 & $11.00 \mathrm{bc}$ & $12.60 \mathrm{bc}$ & 12.47 & 12.45 & $8.68 \mathrm{ab}$ & $8.44 \mathrm{~b}$ \\
\hline$D_{1} M_{3}$ & 16.67 & 13.45 & $14.27 \mathrm{a}$ & $15.00 \mathrm{a}$ & 14.77 & 13.09 & $9.63 \mathrm{a}$ & $10.33 \mathrm{a}$ \\
\hline $\mathrm{D}_{2} \mathrm{M}_{1}$ & 10.69 & 11.55 & $12.87 \mathrm{bc}$ & $11.00 \mathrm{~d}$ & 10.17 & 10.17 & $6.37 \mathrm{~cd}$ & $6.38 \mathrm{de}$ \\
\hline $\mathrm{D}_{2} \mathrm{M}_{2}$ & 13.07 & 12.06 & $11.80 \mathrm{bc}$ & $12.90 \mathrm{c}$ & 11.50 & 12.15 & $7.41 \mathrm{bc}$ & $6.70 \mathrm{de}$ \\
\hline $\mathrm{D}_{2} \mathrm{M}_{3}$ & 14.20 & 13.09 & $14.07 \mathrm{ab}$ & $13.20 \mathrm{~b}$ & 13.63 & 12.75 & $9.33 \mathrm{a}$ & $9.07 \mathrm{ab}$ \\
\hline$D_{3} M_{1}$ & 7.20 & 7.18 & $10.00 \mathrm{~d}$ & $9.60 \mathrm{~d}$ & 8.98 & 8.70 & $5.58 \mathrm{~cd}$ & $5.00 \mathrm{f}$ \\
\hline $\mathrm{D}_{3} \mathrm{M}_{2}$ & 7.57 & 8.86 & $10.33 \mathrm{~d}$ & $11.93 \mathrm{c}$ & 10.08 & 9.58 & $5.71 \mathrm{~cd}$ & $6.70 \mathrm{de}$ \\
\hline $\mathrm{D}_{3} \mathrm{M}_{3}$ & 8.78 & 9.89 & $11.27 \mathrm{~cd}$ & $12.00 \mathrm{c}$ & 11.50 & 10.18 & $5.10 \mathrm{~d}$ & $7.44 \mathrm{~cd}$ \\
\hline $\operatorname{LSD}(0.05)$ & 1.11 & 0.50 & $*$ & $*$ & 0.52 & 0.36 & $*$ & $*$ \\
\hline CV $(\%)$ & 5.30 & 5.95 & 6.74 & 9.60 & 5.54 & 5.81 & 3.66 & 6.32 \\
\hline
\end{tabular}

$D_{1}=30$ Nov. $D_{2}=15$ Dec. $D_{3}=30$ Dec., $M_{1}=$ Low management, $M_{2}=$ Medium management, $M_{3}=$ High management

\section{Conclusion}

The results revealed that temperature variation in different sowing dates influenced highly on phenology, growth and yield of garden pea. Increased temperature enhanced early flowering of late sown garden pea. High temperature from flowering to maturity reduced duration of pod setting and produced lower yield at 30 Dec. sowing. The pod yield reduction was reduced to some extent by high management practices. Two year results revealed that 30 November sowing with high management practices (extra 20\% recommended fertilizer dose, HRC + two irrigation at pre flowering and pod development stage + seed treatment + one weeding at 21 DAE) showed better pod yield than other combinations.

\section{References}

Ali, M.Z., M.A. Aziz, M.A.I. Sarker, S. Mazumder, S.K. Paul, T.A. Mujahidi, M.S.A. Khan and M.S. Bhuiyan. 2016. Effect of sowing time based temperature variations on growth, yield and seed quality of garden pea. Bangladesh Agron. J. 19(1): 29-36.

Bhat, T.A., M. Gupta, M.A. Ganai, R.A. Ahanger and H.A. Bhat. 2013. Yield, soil health and nutrient utilization of field pea (Pisum sativum L.) as affected by phosphorus and Biofertilizers under subtropical conditions of Jammu, Intl. J. M. Plant Anim. Sci. 1(1): 1-8.

Guilioni, L., J. Wery and F. Tardieu. 1997. Heat stress-induced abortion of buds and flowers in pea: is sensitivity linked to organ age or to relations between reproductive organs. Ann. Bot. 80: 159-168.

Helena, Ł. and A. Brodaczewska. 2007. The influence of environmental factors on flowering of French bean (Phaseolus vulgaris). Acta Agrobot. 60(2): 153-159.

Jeuffroy, M.H., C. Duthion, J.M. Meynard and A. Pigeaire. 1990. Effect of a short period of high day temperatures during flowering on the seed number per pod of pea (Pisum sativum L). Agron. EDP Sci. 10(2): 139-145. 
Kaushal, N., R. Awasthi, K. Gupta, P. Gaur, K.H. Siddique and H. Nayyar. 2013. Heat-stress-induced reproductive failures in chickpea (Cicer arietinum) are associated with impaired sucrose metabolism in leaves and anthers. Funct. Plant Biol. 40: 1334-1349.

Kumar, S., P. Thakur, N. Kaushal, J.A. Malik, P. Gaur and H. Nayyar. 2013. Effect of varying high temperatures during reproductive growth on reproductive function, oxidative stress and seed yield in chickpea genotypes differing in heat sensitivity. Arch. Agron. Soil Sci. 59: 823-843.

Mohanty, S.K., B. Baisakih, U.K. Dikshit and B. Bhol. 2001. Kalamung, a promising local mungbean cultivar. Environ. Ecol. 16(1): 222-223.

Slinkard, A.E., G. Bascur and G. Hernandez-Bravo. 1994. Biotic and abiotic stresses of cool season food legumes in the western hemisphere. pp.195-203.

Sousa-Majer. M.J., N.C. Turner, D.C. Hardle, L.R. Morton, L. Morton and J.V. Thomas. 2004. Response to water deficit and high temperature of transgenic peas (Pisum sativum L.). J. Exp. Bot. 55(396): 497-505.

Tewari, S.K. and M. Singh. 1993. Yielding ability of wheat at different date of sowing - a temperature development performance. Indian J. Agron. 38(2): 204-209. 